\title{
Parameters determining the severity of acute pancreatitis
}

\author{
Satish Chandra Yadav* MBBS.MD, Dev Shankar Yadav Msc
}

Department of Internal Medicine, Grande International Hospital, Nepal.

*Corresponding Author: Satish Chandra Yadav, Department of Internal Medicine, Grande International Hospital, Nepal.

Received Date: November 10, 2021 | Accepted Date: January 31, 2021 | Published Date: February 07, 2022

Citation: Satish C Yadav, Dev S Yadav. (2022). Parameters determining the severity of acute pancreatitis. International Journal of Clinical Case Reports and Reviews. 10(4); DOI:10.31579/2690-4861/192

Copyright: () 2022 Satish Chandra Yadav, This is an open-access article distributed under the terms of the Creative Commons Attribution License, which permits unrestricted use, distribution, and reproduction in any medium, provided the original author and source are credited.

\begin{abstract}
Early determination of the severity of pancreatitis can help in guiding the mode of treatment and predicting the disease outcomes. The severity of acute pancreatitis can be determined by history, physical examination, laboratory markers, and radiological examinations. Among these parameters CRP, Ranson, Glasgow are simple and cost effective test, which is useful in clinical practice. APACHE II score, Balthazar score, BISAP score and cytokines are the best parameters to determine the severity and disease outcomes.
\end{abstract}

Keywords: acute pancreatitis, Ranson's score, APACHE II score, and Balthazar score

\section{Introduction}

About (15-25) \% of AP changed into SAP over time. One study shows that the death rate decreased from $12 \%$ to $2 \%$ from 1988 to 2003 in the USA but remains high in other place [1]. Determining severity can guide the mode of treatment and prevent death. The severity of pancreatitis are determined by history, physical examination, laboratory, markers, and radiological examinations; these parameters including grading system has been developed to determine the severity of pancreatitis [2], among this grading system few test are specific when done at the time of admission while others are done at (48-72) hours or later. These systems have low specificity together with low prevalence give poor predictive values [3]. For better predictive values biomarkers, genetic polymorphisms and mutations, and proteomic and metabolomic patterns should be included [4].

\section{Laboratory, Radiologic and Grading System Predictors}

\section{Amylase and Lipase}

Serum lipase rises 4 to 8 hours from the onset of symptoms and normalizes within 7 to 14 days after treatment. Serum amylase may be normal in $10 \%$ of cases of acute or chronic pancreatitis due to depleted acinar cell mass and hypertriglyceridemia. False-positive serum amylase is seen in salivary gland disease (elevated salivary amylase), bowel obstruction, infarction, cholecystitis, and a perforated ulcer. If the lipase level is about 2.5 to 3 times that of amylase, it is an indication of pancreatitis due to alcohol, decreased serum calcium, and glycosuria.

\section{C-reactive protein}

C-reactive protein (CRP) is an annular, pentameric protein found in blood plasma, whose level rises in response to inflammation. It is an acute-phase protein of hepatic origin that increases following interleukin-6 secretion by macrophages and T cells. Its physiological role is to bind to lysophosphatidylcholine expressed on the surface of dead or dying cells and some types of bacteria to activate the complement system via the C1Q complex [5]. CRP is synthesized by the liver [6] in response to factors released by macrophages and fat cells [7]. It is a member of the pentraxin family of proteins (6). C-reactive protein was the first pattern recognition receptor (PRR) to be identified [8].

C-reactive protein (CRP) is one of the acute phase reactants made by the liver in response to interleukin-1 and interleukin-6. Levels of CRP above $150 \mathrm{mg} / \mathrm{L}$ at 48 hours discriminate severely from mild disease. At 48 hours, CRP above $150 \mathrm{mg} / \mathrm{L}$ has a sensitivity, specificity, positive predictive value, and negative predictive value of $80,76,67$, and 86 percent, respectively, for severe acute pancreatitis [7]. CRP rises steadily with the severity of pancreatitis, is inexpensive to measure, and testing is readily available [8-10]. As a result, it is used to predict the severity of pancreatitis, especially at 48 hours.

\section{Ranson's score}

Ranson's criteria are one of the oldest criteria for assessing the severity of acute pancreatitis [11]. It includes 11 factors, 5 factors including Age, WBC count, Blood glucose, Serum AST, and Serum LDH are done at the time of admission while other 6 factors including Serum calcium, Hematocrit fall, $\mathrm{PaO} 2, \mathrm{BUN}$, Base deficit, Sequestration of fluids are done within 48 hours of admission (Table 1). A Ranson's score of more than 3 is most likely to be severe pancreatitis and a score less than 3 is least likely to be severe pancreatitis [12]. It also predicts the mortality rate, scores less than 3 mortality rate is $0-3 \%$, score more than 3 mortality rate (11-15) \%, and score more than 6 mortality rate $40 \%$ [13]. One metaanalysis results show it is a poor predictor of severity [14]. However, this scoring system is still continuously being used in clinical practice. 


\begin{tabular}{|c|c|c|}
\hline & At the time of admission: & \\
\hline 1 & Age & $>55$ years \\
\hline 2 & White blood cell count & $>16,000 / \mathrm{mm}^{3}$ \\
\hline 3 & Blood glucose & $>200 \mathrm{mg} / \mathrm{dL}(11.1 \mathrm{mmol} / \mathrm{L})$ \\
\hline 4 & Aspartate aminotransferase (AST) & $>250 \mathrm{U} / \mathrm{L}$ \\
\hline \multirow[t]{2}{*}{5} & Serum Lactate dehydrogenase & $>350 \mathrm{U} / \mathrm{L}$ \\
\hline & Within 48 hours of the admission & \\
\hline 1 & Serum calcium & $<2 \mathrm{mmol} / \mathrm{L}(<8 \mathrm{mg} / \mathrm{dL})$ \\
\hline 2 & Blood urea nitrogen(BUN) & $\begin{array}{c}\text { Increase by } \geq 5 \mathrm{mg} / \mathrm{dL}(1.8 \mathrm{mmol} / \mathrm{L}) \text { despite } \\
\text { IV fluid hydration }\end{array}$ \\
\hline 3 & Hematocrit & Fall by $\geq 10 \%$ \\
\hline 4 & $\mathrm{PaO}_{2}$ & $<60 \mathrm{mmHg}$ \\
\hline 5 & Base deficit & $>4 \mathrm{mEq} / \mathrm{L}$ \\
\hline 6 & Fluid sequestation & $>6000 \mathrm{~mL}(>6 \mathrm{~L})$ \\
\hline
\end{tabular}

Table 1: Ranson criteria to predict severity of acute pancreatitis: The presence of 1 to 3 criteria represents mild pancreatitis; the mortality rate rises significantly with four or more criteria. $\mathrm{PaO} 2$. (Partial pressure of oxygen)

\section{APACHE II}

Acute Physiology and Chronic Health Evaluation II (APACHE II) is the severity of the disease classification system. It was developed in 1985 by Knaus et al. for critically ill patients in intensive care units (ICUs) [15]. APACHE II scores are calculated within 24 hours of admission. It is probably the most widely studied severity scoring system in AP and can be performed daily. It has 12 physiologic measures and extra points based upon age and the presence of chronic disease. The following parameters are calculated in APACHE II: $\mathrm{AaDO} 2$ or $\mathrm{PaO} 2$ (depending on $\mathrm{FiO} 2$ ), Temperature (rectal), Mean arterial pressure, $\mathrm{pH}$ arterial, Heart rate, Respiratory rate, Sodium (serum), Potassium (serum), Creatinine, Hematocrit, White blood cell count, and Glasgow Coma Scale.

APACHE II was designed to measure the severity of disease for adult patients admitted to intensive care units. It has not been validated for use in children or young people aged less than 16. This scoring system helps in many ways these includes:

1. Some procedures or some medicines are only given to patients with a certain APACHE II score

2. APACHE II score helps to determine the morbidity of a patient when comparing the outcome with other patients.

3. Predicted mortalities are averaged for groups of patients to specify the group's morbidity.

APACHE II scores vary from 0 to 71 . The different parameters and scores are shown in (fig.1). Decreasing values during the first 48 hours suggest a mild attack while increasing values suggest a severe attack. Studies show that mortality is less than $4 \%$ with a score $<8$ and is more $(11-18)$ $\%$ with a score $>8[16, \mathbf{1 7}]$.

The first APACHE model was presented by Knaus et al. in 1981 [18]. Later it was modified in 1985 by Knaus and named as APACHE II. Some limitations of the APACHE II score are that; it is complex and cumbersome to use, it does not differentiate between interstitial and necrotizing pancreatitis, and it does not differentiate between sterile and infected necrosis. Finally, it has a poor predictive value at 24 hours [17].

Several additional variables were added to APACHE II to improve its accuracy leading to the development of APACHE III in 1991 [19]. Both APACHE II and III scores use physiology, age, and chronic health to calculate prognosis; they differ in total score, the number of physiologic variables (12 for APACHE II versus 17 for APACHE III), and the assessment of chronic health status. However, the APACHE III system does not appear to be as useful as APACHE II for distinguishing mild from severe attack [20]. APACHE III scores range from 0 to 299(19). Even though newer scoring systems, such as SAPS II, APACHE III developed, APACHE II continues to be used extensively.

\section{Balthazar score}

In the early 1990s, the Balthazar score was developed by Emil J. Balthazar et al [21]; it is a Computed Tomography Severity Index (CTSI) grading system used to determine the severity of acute pancreatitis. It is based upon the degree of necrosis, inflammation, and the presence of fluid collections [21]. The numerical CTSI has a maximum of ten points, the sum of the Balthazar grade points and pancreatic necrosis grade points are shown in (TABLE 2.). 
The APACHE II Severity of Disease Classification System

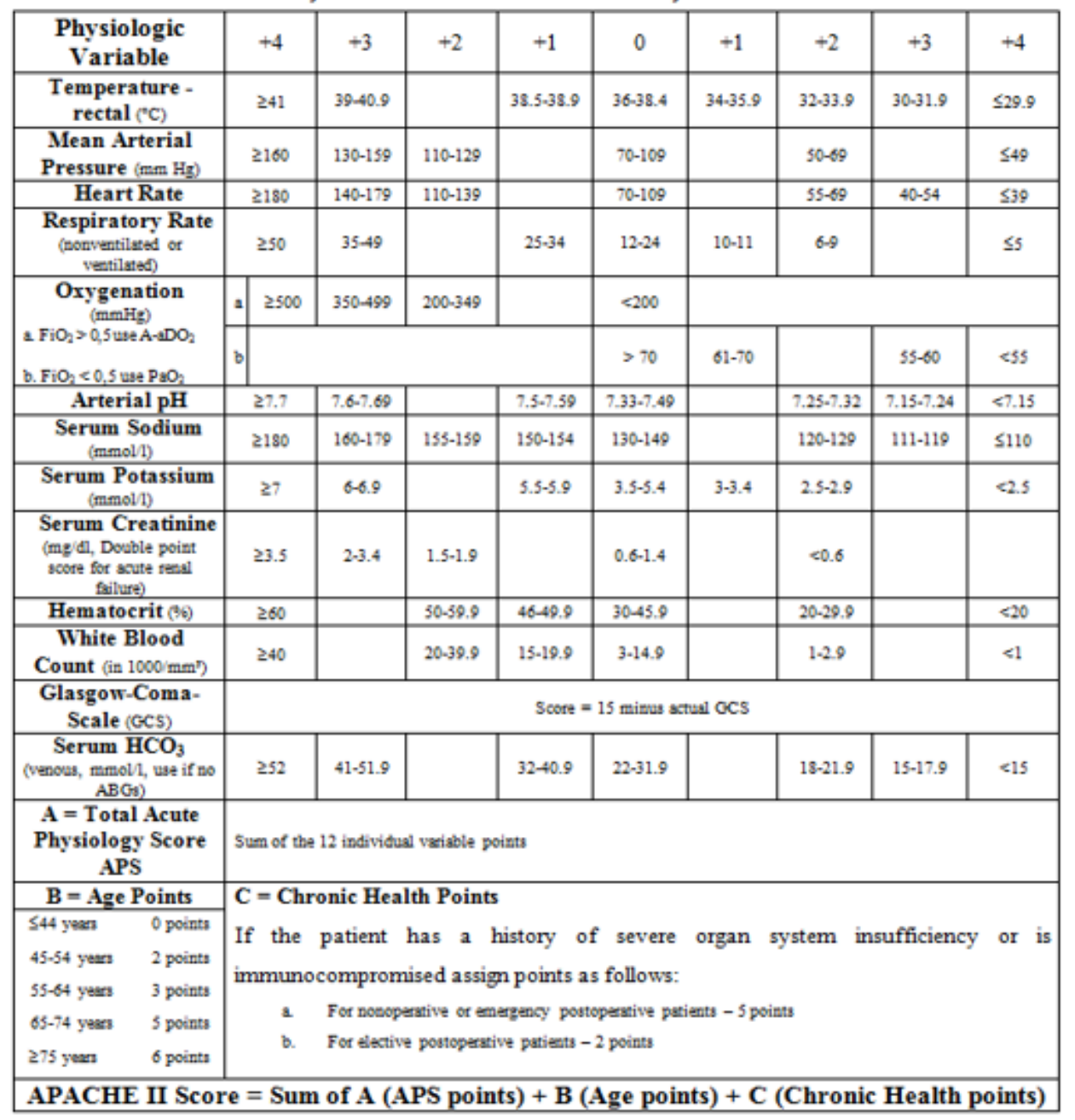

(From: Knaus WA, Draper EA, Wagner DP, Zimmerman JE. APACHE II: a severity of disease classification system. Crit Care Med 1985;13(10):818-29)

Figure 1: APACHE II score (0 to 71) and different parameters are shown.

\begin{tabular}{|l|l|c|}
\hline Grade & \multicolumn{1}{|c|}{ Balthazar Score } & Points \\
\hline A & Normal pancreas & $\mathbf{0}$ \\
\hline B & Pancreatic enlargement & $\mathbf{1}$ \\
\hline C & Pancreatic inflammation and/or peripancreatic fat & $\mathbf{2}$ \\
\hline D & Single peripancreatic fluid collection & $\mathbf{3}$ \\
\hline E & Two or more fluid collections and/or retroperitoneal air & $\mathbf{4}$ \\
\hline \multirow{4}{*}{} & Percentage necrosis & \\
\cline { 2 - 3 } & 0 & $\mathbf{0}$ \\
\cline { 2 - 3 } & $<30$ & $\mathbf{2}$ \\
\cline { 2 - 3 } & $30-50$ & $\mathbf{4}$ \\
\cline { 2 - 3 } & $>50$ & $\mathbf{6}$ \\
\cline { 2 - 3 } & & $\mathbf{0 - 3}$ \\
\cline { 2 - 3 } & CT Severity Index & $\mathbf{4 - 6}$ \\
\cline { 2 - 3 } & Low degree \\
\cline { 2 - 3 } & Middle degree (6\% mortality) & \\
\cline { 2 - 3 } & & \\
\cline { 2 - 3 } & & \\
\hline
\end{tabular}

Table 2: Balthazar grading system and different parameters.

Each of the two sections has a different grading of CT that is awarded a different number of points, increasing proportionally with the severity of AP.

$\mathrm{CT}$ severity index $=\mathrm{CT}$ grade points + Necrosis points
The maximum score obtainable, the sum of the maximum Balthazar grade points and pancreatic necrosis points is 10 .

There are threescore ranges suggestive of different degrees of AP severity: 
- $\quad 0-3$ : score consistent with mild AP;

- 4-6: score consistent with moderate AP;

- 7 -10: the score is consistent with severe AP.

In an initial validation study, mortality was $23 \%$ with any degree of pancreatic necrosis and $0 \%$ with no necrosis. In addition, there was a strong association between necrosis $>30 \%$ and morbidity and mortality [21]. The finding of necrotizing pancreatitis (or even infected necrosis) does not necessarily predict the occurrence of organ failure, but may alter the therapeutic approach [22]. In a retrospective study of 268 patients with AP assessed by the CT severity index, patients with a CT severity index $>5$ were 8 times more likely to die, 17 times more likely to have a prolonged hospital course, and 10 times more likely to undergo necrosectomy than the patients with scores $<5[23]$.

CTSI's staging of acute pancreatitis severity has been shown by many studies to provide a more accurate assessment than APACHE II, Ranson, and C-reactive protein (CRP) level [24-27]. However, a few studies indicate that CTSI is not significantly associated with the prognosis of hospitalization in patients with pancreatic necrosis, nor is it an accurate predictor of AP severity [28, 29].

\section{BISAP score}

Development of the bedside index of severity in acute pancreatitis (BISAP) score was based upon 17,922 cases of AP from 2000 to 2001 and validated in 18,256 cases from 2004 to 2005 [30]. Patients are assigned 1 point for each of the following during the first 24 hours: BUN $>25 \mathrm{mg} / \mathrm{dL}$, impaired mental status, SIRS, age $>60$ years, or the presence of a pleural effusion (TABLE 3) [30]. Patients with a score of zero had a mortality of less than one percent, whereas patients with a score of five had a mortality rate of 22 percent. In the validation cohort, the BISAP score had similar test performance characteristics for predicting mortality as the APACHE II score. As is a problem with many of the other scoring systems, the BISAP has not been validated for predicting outcomes such as length of hospital stay, need for ICU care, or need for intervention.

\begin{tabular}{|c|c|}
\hline \multicolumn{2}{|c|}{$\begin{array}{l}\text { - BUN }>25 \\
\text { - Impaired mental status } \\
\text { - SIRS (> } 2 \text { criteria) } \\
\text { - Age > } 60 \text { yrs } \\
\text { - Pleural effusion on CT scan } \\
\text { - } 1 \text { point for the presence of each finding. } \\
\text { BUN, blood urea nitrogen; SIRS, systemic inflammatory response syndrome }\end{array}$} \\
\hline BISAP Score & Observed Mortlity \\
\hline 0 & $0.1 \%$ \\
\hline 1 & $0.4 \%$ \\
\hline 2 & $1.6 \%$ \\
\hline 3 & $3.6 \%$ \\
\hline 4 & $7.4 \%$ \\
\hline 5 & $9.5 \%$ \\
\hline
\end{tabular}

Table 3: Bedside Index for Severity of Acute Pancreatitis (BISAP).

A validation study of the BISAP score that included 185 patients found that its performance was similar to APACHE II, Ranson's criteria, and the CT severity index system [31]. While the BISAP score is meant to be easily calculated at the bedside, it has been noted that to do so is not as simple as was initially reported because four variables need to be considered to determine if SIRS is present [32].

\section{Glasgow criteria}

Indications: Evaluation of acute Pancreatitis Prognosis and severity in first 48 hours of admission [33, 34].

\section{Criteria:}

1. Arterial oxygen partial pressure $<60 \mathrm{mmHg}(8.0 \mathrm{kPa})$

2. Age $>55$ years

3. White Blood Cell Count $>15 \times 10^{\wedge} 3 / \mathrm{mm} 3$

4. Serum Calcium $<8.0 \mathrm{mg} / \mathrm{dl}(2.0 \mathrm{mmol} / \mathrm{L})$

5. Blood Urea Nitrogen $44 \mathrm{mg} / \mathrm{dl}(16 \mathrm{mmol} / \mathrm{L})$

6. Blood Glucose $>180 \mathrm{mg} / \mathrm{dl}(10 \mathrm{mmol} / \mathrm{L})$

7. Serum Albumin $<3.2 \mathrm{~g} / \mathrm{dl}(32 \mathrm{~g} / \mathrm{L})$

8. Lactate Dehydrogenase $>(600 \mathrm{IU} / \mathrm{L})$
Interpretation: More than 3 criteria present within first 48 hours of presentation are likely to be Severe Pancreatitis [33, 34].

\section{Cytokines}

Cytokines are a group of proteins involved in the innate and adaptive immune systems. Many types of cells in the body-not only immune system cells-can produce cytokines, and production is generally stimulated by the presence of an antigen. Cytokines carry signals from one cell to another, alter cell behavior in various ways and regulate the body's immune response to a potential threat - which could be a pathogen, such as a virus, bacterium, or parasite, or a toxin. In some cases, inappropriate cytokine production takes place in response to something harmless, resulting in an allergic reaction. Usually, cytokine proteins are not stored ready-made but are synthesized when needed.

The role of these proteins in the immune response is complex. A single cytokine can influence several different types of cells and can perform more than one function, while several different cytokines can perform the same function. Different types of cells can respond differently to the same cytokine and cytokines can interact with one another in various ways for example, one might inhibit the effects of another; two together might produce a synergistic effect, and one cytokine may stimulate the production of others. Cytokines can influence the cell that produced them - these are known as autocrine - or they can influence nearby cells - 
these are known as paracrine. Less commonly, they might influence cells some distance away via the bloodstream - these are known as endocrine.

A number of different cytokines are involved with the innate immune system. Chemokines influence the movement of immune cells by chemotaxis and can attract these cells to sites of injury or infection. Tumor necrosis factor alpha (TNF- $\alpha$ ), interleukin 1 (IL-1) and interleukin 6 (IL6 ), known collectively as endogenous pyrogens, cause fever and an inflammatory response to infection by influencing temperature control in the hypothalamus and promoting the breakdown of fat and protein to generate heat; they also stimulate the production of chemokines. Interferons have a variety of functions, including preventing viral replication and activating macrophages and NK cells. Interleukin 10 (IL10), in contrast, has an essentially inhibitory effect on the immune response.

Although these proteins play a vital role in coordinating the immune response to eliminate threats, they can sometimes aggravate conditions caused by pathogens or cause disease themselves. Excessive production of cytokines, perhaps in response to a new and unfamiliar pathogen, can result in what is known as a cytokine storm, which can cause severe and life-threatening inflammation of tissue. It has been suggested that the high mortality rate during the 1918 influenza pandemic was due to this effect rather than the direct effects of the virus itself. Other related problems include toxic shock, allergies and autoimmune diseases. Some cancer cells produce cytokines which help stimulate their growth.

\section{Conclusions}

During the initial 24 hours, severe acute pancreatitis (AP) can be predicted using clinical, laboratory, and radiologic parameters, many of which have been incorporated into scoring systems such as the systemic inflammatory response syndrome (SIRS) score, the Acute Physiology and Chronic Health Examination (APACHE) II score, the bedside index of severity in acute pancreatitis score, and the computed tomography (CT) severity index. We favor the SIRS score because it is simple, cheap, readily available, and as accurate as any other complex scoring system, especially persistent SIRS.

We suggest a contrast-enhanced CT be performed in patients considered to have severe AP based upon clinical criteria or possibly the APACHE II score to determine if necrotizing pancreatitis is present. A CT scan is not required on the first day unless other diagnoses are being considered. It takes time for pancreatic necrosis to develop and thus CT may be normal in the first 48 to 72 hours. Although there are some experimental data that ionic contrast may worsen pancreatitis, the association is probably not strong and the information obtained from the CT scan justifies the potential risk.

Magnetic resonance imaging is emerging as a useful imaging tool in pancreatitis, especially to identify stones in the bile duct, visualize pancreatic duct, and to distinguish the contents of fluid collections seen on CT. However, experience remains inadequate in the setting of acute pancreatitis primarily because of its high cost and need for prolonged examination time.

Laboratory tests have an adjunctive role in predicting the severity of acute pancreatitis. We agree with the guidelines issued by the American College of Gastroenterology and International Association of Pancreatology/ American Pancreatic Association, which suggest that advanced age, comorbidities, body mass index $>30$, pleural effusion or pulmonary infiltrates, hematocrit $>44$, blood urea nitrogen $(\mathrm{BUN})>20$, rising BUN, high creatinine, initial SIRS score $\geq 2$, persistent SIRS, and persistent organ failure as predictors of severe disease.

In Summary: CRP, Ranson, Glasgow are simple and cost effective test, which is useful in clinical practice. APACHE II score, Balthazar score,
BISAP score and cytokines are the best parameters to determine the severity and disease outcomes.

\section{Abbreviations}

APACHE: acute physiology and chronic health evaluation;

CRP: C-reactive protein;

SAP: severe acute pancreatitis;

\section{IL: Interleukin}

\section{SIRS: Systemic inflammatory response syndrome}

TNF- $\alpha$ : Tumor necrosis factor alpha

Conflict of interest: There is no conflict of interest to declare.

\section{References}

1. Fagenholz PJ, Castillo CF, Harris NS, et al. (2007). Increasing United States hospital admissions for acute pancreatitis, 19882003. Ann Epidemiol. 17:491.

2. Windsor JA. (2000). Search for prognostic markers for acute pancreatitis. Lancet. 355:1924.

3. Robert JH, Frossard JL, Mermillod B, et al. (2002). Early prediction of acute pancreatitis: prospective study comparing computed tomography scans, Ranson, Glascow, Acute Physiology and Chronic Health Evaluation II scores, and various serum markers. World J Surg. 26:612.

4. Chauhan S, Forsmark CE. (2010). The difficulty in predicting outcome in acute pancreatitis. Am J Gastroenterol. 105:443.

5. Lau DC, Dhillon B, Yan H, Szmitko PE, Verma S. (2005). "Adipokines: molecular links between obesity and atheroslcerosis". American Journal of Physiology. Heart and Circulatory Physiology. 288(5):2031-2041.

6. Mantovani A, Garlanda C, Doni A, Bottazzi B. (2008). "Pentraxins in innate immunity: from C-reactive protein to the long pentraxin PTX3". Journal of Clinical Immunology. 28 (1):1-13.

7. Larvin M. (1998). Assessment of clinical severity and prognosis. In: The Pancreas, Beger HG, Warshaw AL, Buchler MW, et al (Eds), Blackwell Science, Oxford. 489.

8. Büchler M, Malfertheiner P, Schoetensack C, et al. (1986). Sensitivity of antiproteases, complement factors and C-reactive protein in detecting pancreatic necrosis. Results of a prospective clinical study. Int J Pancreatol. 1:227.

9. Wilson C, Heads A, Shenkin A, Imrie CW. (1989). C-reactive protein, antiproteases and complement factors as objective markers of severity in acute pancreatitis. Br J Surg. 76:177.

10. Leese T, Shaw D, Holliday M. (1988). Prognostic markers in acute pancreatitis: can pancreatic necrosis be predicted? Ann R Coll Surg Engl. 70:227.

11. Ranson JH, Rifkind KM, Roses DF, et al. (1974). Prognostic signs and the role of operative management in acute pancreatitis. Surg Gynecol Obstet. 139:69.

12. Ranson JH. (1979). The timing of biliary surgery in acute pancreatitis. Ann Surg. 189:654.

13. Banks PA, Freeman ML. (2006). Practice Parameters Committee of the American College of Gastroenterology. Practice guidelines in acute pancreatitis. Am J Gastroenterol. 101:2379.

14. De Bernardinis M, Violi V, Roncoroni L, et al. (1999). Discriminant power and information content of Ranson's prognostic signs in acute pancreatitis: a meta-analytic study. Crit Care Med. 27:2272. 
15. Knaus WA, Draper EA, Wagner DP, Zimmerman JE. (1985). "APACHE II: a severity of disease classification system". Critical Care Medicine. 13(10):818-829.

16. Larvin M. (1998). Assessment of clinical severity and prognosis. In: The Pancreas, Beger HG, Warshaw AL, Buchler MW, et al (Eds), Blackwell Science, Oxford. 489.

17. Banks PA, Freeman ML, (2006). Practice Parameters Committee of the American College of Gastroenterology. Practice guidelines in acute pancreatitis. Am J Gastroenterol. 101:2379.

18. Knaus WA, Zimmerman JE, Wagner DP, Draper EA, Lawrence DE. (1981). "APACHE-acute physiology and chronic health evaluation: a physiologically based classification system". Critical Care Medicine. 9(8):591-597.

19. Knaus WA, Wagner DP, Draper EA, Zimmerman JE, Bergner M, Bastos PG, Sirio CA, Murphy DJ, Lotring T, Damiano A, et al. (1991). "The APACHE III prognostic system. Risk prediction of hospital mortality for critically ill hospitalized adults". Chest. 100(6): 1619-1636.

20. Williams M, Simms HH. (1999). Prognostic usefulness of scoring systems in critically ill patients with severe acute pancreatitis. Crit Care Med. 27:901.

21. Balthazar EJ, Robinson DL, Megibow AJ, Ranson JH. (1990). Acute pancreatitis: value of CT in establishing prognosis. Radiology. 174:331.

22. Tenner S, Sica G, Hughes M, et al. (1997). Relationship of necrosis to organ failure in severe acute pancreatitis. Gastroenterology. 113:899.

23. Simchuk EJ, Traverso LW, Nukui Y, Kozarek RA. (2000). Computed tomography severity index is a predictor of outcomes for severe pancreatitis. Am J Surg. 179:352.

24. Gürleyik G, Emir S, Kiliçoglu G, Arman A, Saglam A. (2005). "Computed tomography severity index, APACHE II score, and serum CRP concentration for predicting the severity of acute pancreatitis". JOP. 6(6):562-567.
25. Knoepfli AS, Kinkel K, Berney T, Morel P, Becker CD, Poletti PA. (2007). "Prospective study of 310 patients: can early CT predict the severity of acute pancreatitis?". Abdominal Imaging. 32(1):111-115.

26. Leung TK, Lee CM, Lin SY, Chen HC, Wang HJ, Shen LK, Chen YY. (2005). "Balthazar computed tomography severity index is superior to Ranson criteria and APACHE II scoring system in predicting acute pancreatitis outcome". World J Gastroenterol. 11(38): 6049-6052.

27. Vriens PW, van de Linde P, Slotema ET, Warmerdam PE, Breslau PJ. (2005). "Computed tomography severity index is an early prognostic tool for acute pancreatitis". J Am Coll Surg. 201(4):497-502.

28. Triantopoulou C, Lytras D, Maniatis P, Chrysovergis D, Manes K, Siafas I, Papailiou J, Dervenis C. (2007). "Computed tomography versus Acute Physiology and Chronic Health Evaluation II score in predicting severity of acute pancreatitis: a prospective, comparative study with statistical evaluation". Pancreas. 35(3):238-242.

29. Mortelé KJ, Mergo PJ, Taylor HM, Wiesner W, Cantisani V, Ernst MD, Kalantari BN, Ros PR (2004). "Peripancreatic vascular abnormalities complicating acute pancreatitis: contrastenhanced helical CT findings". Eur J Radiol. 52 (1):67-72.

30. Wu BU, Johannes RS, Sun X, et al. (2008). The early prediction of mortality in acute pancreatitis: a large population-based study. Gut. 57:1698.

31. Papachristou GI, Muddana V, Yadav D, et al. (2010). Comparison of BISAP, Ranson's, APACHE-II, and CTSI scores in predicting organ failure, complications, and mortality in acute pancreatitis. Am J Gastroenterol. 105:435.

32. Windsor JA. (2010). A better way to predict the outcome in acute pancreatitis?. Am J Gastroenterol. 105:1671.

33. Barreto. (2007). World J Emerg Surg 2:33.

34. Moore. (2000). Ann R Coll Surg Engl. 82(1):16-17.

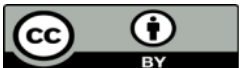

This work is licensed under Creative Commons Attribution 4.0 License

To Submit Your Article Click Here:

Submit Manuscript

DOI: $10.31579 / 2690-4861 / 192$
Ready to submit your research? Choose Auctores and benefit from:

$>$ fast, convenient online submission

$>$ rigorous peer review by experienced research in your field

$>$ rapid publication on acceptance

$>$ authors retain copyrights

$>$ unique DOI for all articles

$>$ immediate, unrestricted online access

At Auctores, research is always in progress.

Learn more https://auctoresonline.org/journals/international-journal-of-clinicalcase-reports-and-reviews 